\title{
Taking the Lead in the Time of COVID-19 Pandemic: A Perspective from the Philippine Financial Industry
}

\author{
Erick John E. Endres \\ School of Business and Governance \\ Ateneo de Davao University, Davao City, Philippines \\ DOI: 10.29322/IJSRP.10.07.2020.p10307 \\ http://dx.doi.org/10.29322/IJSRP.10.07.2020.p10307
}

\begin{abstract}
This paper attempts to explore the traits that leaders should possess in the time of COVID-19 pandemic. The study utilized a qualitative research design and solicited 58 responses from employees in the financial industry to capture the prevailing traits of business leaders. The reflexive thematic analysis showed that leaders, among others, should be empathetic, responsible, transparent, resilient and supportive. The participant-employees perceived these traits as necessary not just for their leaders' effective governance but for the organization's survival as a whole.
\end{abstract}

Index Terms - Leadership, Trait Theory, COVID-19, Pandemic, Financial Industry, Philippines

\section{INTRODUCTION}

The first case of the deadly Coronavirus disease 2019, also known as COVID-19, was recorded in November 2019 in Wuhan, China (South China Morning Post, 2020). The government leaders were confident to contain the virus within the Chinese territory until January 2020 when the first case was confirmed in Thailand (World Health Organization, 2020). On March 11, 2020, with over 118,000 cases in around 110 countries, the World Health Organization declared the virus as a pandemic (Time, 2020). The announcement triggered a dreadful challenge among leaders across financial markets with looming distress worse than the global financial crisis in 2008. Giant economies like the US, China and Japan succumbed to economic instability, and with economies under lockdown, business leaders began to realize financial and manpower losses.

In the Philippines with its struggling economy, the government leaders placed initiatives to mitigate the impact of the pandemic through monetary and fiscal policy stimulus for the business sectors, distribution of financial aids for the underprivileged, and health care assistance for the infected Filipinos. Likewise, financial industry leaders shifted gears from business-centric to people-centric as they implemented alternative business models, work-fromhome arrangements, advance salary payments and waiver of interests on employee loans. In this time of pandemic, 
people in an organization is like a sheep waiting for the shepherd's guidance. As organizations embrace the new normal of doing things, employees look up to their leaders in terms of direction and motivation to get things done while staying safe. Nevertheless, true leaders emerge with noticeable traits in achieving organizational commitments and goals while ensuring the welfare of their people.

The study is anchored to the Trait Theory of Leadership which can be traced from the works of Thomas Carlyle (Spector, 2016). The theory suggests the correlation of inborn personality traits to successful leadership. In particular, the theory was based on the rationale that traits produce behavioral patterns that are consistent across various situations (Yuki, 2006; Zaccaro, Kemp, \& Bader, 2004). The proponents of this theory believe that successful leaders have a definite set of skills, abilities and personality traits that are different from less effective leaders. Galton (1869) added that some of the immutable traits cannot be developed over time while Derue, Nahrgang, Wellman and Humphrey (2011) pronounced that understanding these personality traits may help organizations plan for leadership succession. On the other hand, psychologists Ralph Stogdill believed that leadership is a product of the interaction between the individual and the social situation (Oakleaf, 2016). Other scholars commented that the theory is unidimensional and focuses only on the follower's perception (Conger \& Kanugo, 1998; Lord, De Vader, \& Alliger, 1986). Also, Kouzes and Posner (2019) argued that credibility is a key indicator of leadership skills while Kumar, Adhish and Deoki (2014) posited that leadership is somehow predestined but not in all cases.

Though various studies were already undertaken regarding the vast aspects of leadership in the Philippines, none of the literature was done during the pandemic. Knowing that there is still no available vaccine for the virus at the time of publication of this paper, materials for both quantitative and qualitative types of research are still very scarce. Thus, this paper contributes to the early literature about the prevailing traits that leaders should possess in the time of COVID-19 pandemic.

\section{LITERATURE REVIEW}

\section{A. The Big Five Personality Traits}

To reduce the innumerable traits produced in a decade of studies, Tupes and Raymond (1961), Digman (1990), and Goldberg (1993) introduced a model also known as the Big Five Model which captures broadly defined traits into five domains. The domains included are extraversion, conscientiousness, agreeableness, emotional stability and openness (Hough, 1992; Judge, Bono, Ilies \& Gerhardt, 2002). Salgado (1997) found that all domains except for openness were significant predictors of job performance in the European community while Stevens and Ash (2001) posited that only conscientiousness and extroversion were positively correlated with a preference for managerial work and job performance. However, Crant and Bateman (2000) argued that only extroversion was related to perceptions of charismatic leadership. Judge et al. (2002) also pronounced that extroversion had the strongest correlation to leadership. 


\section{B. Resilient Leaders}

According to Southwick, Martini, Charney and Southwick (2017), resilience can be defined as the ability to regain balance after an adverse event. It is a process instead of a result (Southwick, Litz, Charney \& Friedman, 2011) and those resilient leaders can adapt to stress and maintain a healthy mindset amidst management crisis (Krystal, 2008; Reich, Zautra \& Hall, 2010). Added by Joy (2017), the real test of leaders is when they manifest strength, audacity and professionalism in difficult situations. Yehuda, Flory, Southwick, and Charney (2006) pronounced that the resiliency of a leader depends on numerous genetic, neurobiological, developmental and psychological factors. Furthermore, resilient leaders are realistically optimistic and that they understand the implications of over and underestimation of potential risks that may result in organizational failure (Kruger \& Dunning, 1999; Reivich \& Shatte, 2003).

\section{Supportive Leaders}

Supportive behavior is among the significant factors that contribute to effective leadership (Brearley, 2020). Simmons (2010) hypothesized that supportive leadership may enhance work performance. According to Yukl (2010), there are 9 behaviors that supportive leaders should work on: show acceptance and positive regard for others, be polite, treat the employee as an individual, remember important details, be patient, provide sympathy, express confidence, provide assistance, and be willing to help with personal problems. Lane (2019), in her article, mentioned that supportive leaders should build on the strengths of others, and empower and inspire. Leaders should recognize the expertise and acknowledge the value of team members while at the same time listen to every opinion and offer equal opportunity for assignments, training and promotions. Likewise, supportive leaders should encourage teamwork, show commitment and focus on relationships (CFI, 2020).

\section{Empathetic Leaders}

Empathy is defined as a skill of understanding the feelings, emotions, interests and concerns of other people (Decety, Philip \& Jackson, 2006; Goleman, 2000; Marques, 2010; Mencl \& May, 2009). Likewise, Gentry, Weber and Sadri (2016) defined empathy as the ability to experience the thoughts and emotions of others. It is essential to transformational leadership to show that leaders care for his/her team members (Bass, 1985). Likewise, empathy is crucial to effective leadership (Bar-On \& Parker, 2000; George, 2000; Marques, 2010; Salovey \& Mayer, 1990). Empathy, as a skill, allows leaders to understand the perspective of others by placing themselves in the same situation (Gardner \& Stough, 2002; Voss, Gruber and Reppel, 2010). Empathic leaders are more open about diversity (Atwater \& Waldman, 2008), likely to develop trust in the leader-follower relationship (Martinovski, Traum \& Marsella, 2007), and sensitive to changes in the work environment (Tager, 2004). 


\section{E. Transparent Leaders}

Transparent leaders listen and communicate questions to encourage discussions and promote innovative thinking among team members (Leonard, 1999). According to Llopis (2012), transparent leaders solve problems faster, built teams easier, grow a genuine relationship, promote trust, and develop high work performance. Open communication is essential to effective organizations (Gross, 2002; Myers, Knox, Palowski \& Ropog, 1999), better leader-employee relationship (Kay \& Christophel, 1995), job satisfaction (Weiss, 2002), role clarity (Klaus \& Bass, 1982) and positive peer relationship (Myers et al., 1999). Transparency is vital to authentic leadership (Gardner, Avolio, Luthans, May \& Walumbwa, 2005) which develops greater trust between the leader and followers (Hughes, 2005; Walumbwa, Avolio, Gardner, Wernsing \& Peterson, 2008). Furthermore, Han (2017) determined that leaders' transparent behavior influences creativity among employees.

\section{F. Responsible Leaders}

According to Maak and Pless (2006), responsible leadership is a social process wherein leaders sort things based on ethical considerations to create a more sustainable and trustful relationship with the stakeholders. Further, they emphasize the relationship is vital to responsible leadership. Leaders with empathy can easily understand the needs of the stakeholders and act promptly, thus they are more likely to become responsible leaders (Dietz \& Kleinlogel, 2014; Muller, Pfarrer \& Little, 2014; Stahl \& de Luque, 2014). Likewise, moral intensity and cultural value orientations greatly influence leaders' responsible behaviors (Stahl \& de Luque, 2014). Moreover, responsible leadership reduces employee turnover ratio (Doh, Stumpf \& Tymon Jr., 2011), improves job satisfaction among employees (Voegtlin, 2011), and promotes organizational commitment (Doh, Quigley, 2014).

\section{METHODOLOGY}

The qualitative research design using a reflexive approach of thematic analysis was designed to capture the emerging traits of leaders across financial industries during the time of COVID-19 pandemic in the Philippines. Qualitative research is appropriate for the study since it allows a full and in-depth review of the phenomenon being studied (Corbin \& Strauss, 2008; Hill, Thompson \& Williams, 1997). The inductive style was adopted in the survey since it captures raw ideas from the participants. It works from specific observation and relates to broader themes and generalizations (Burney \& Saleem, 2008).

The survey was administered from May 5 to 25, 2020, using two online channels such as LinkedIn and Viber. The total valid responses were 58 out of the 59 collected. One response was scrapped due to an invalid character submitted by a participant. The single open-ended question used in the survey was: "In your own opinion as an employee, what are the most significant traits that leaders in your organization should possess in this time of COVID-19 pandemic?”. 
After reviewing the validity of the responses, the researcher proceeded with the thematic analysis using the six-phase approach recommended by Braun and Clarke (2006). The procedures with corresponding examples are enumerated in Figure 1.

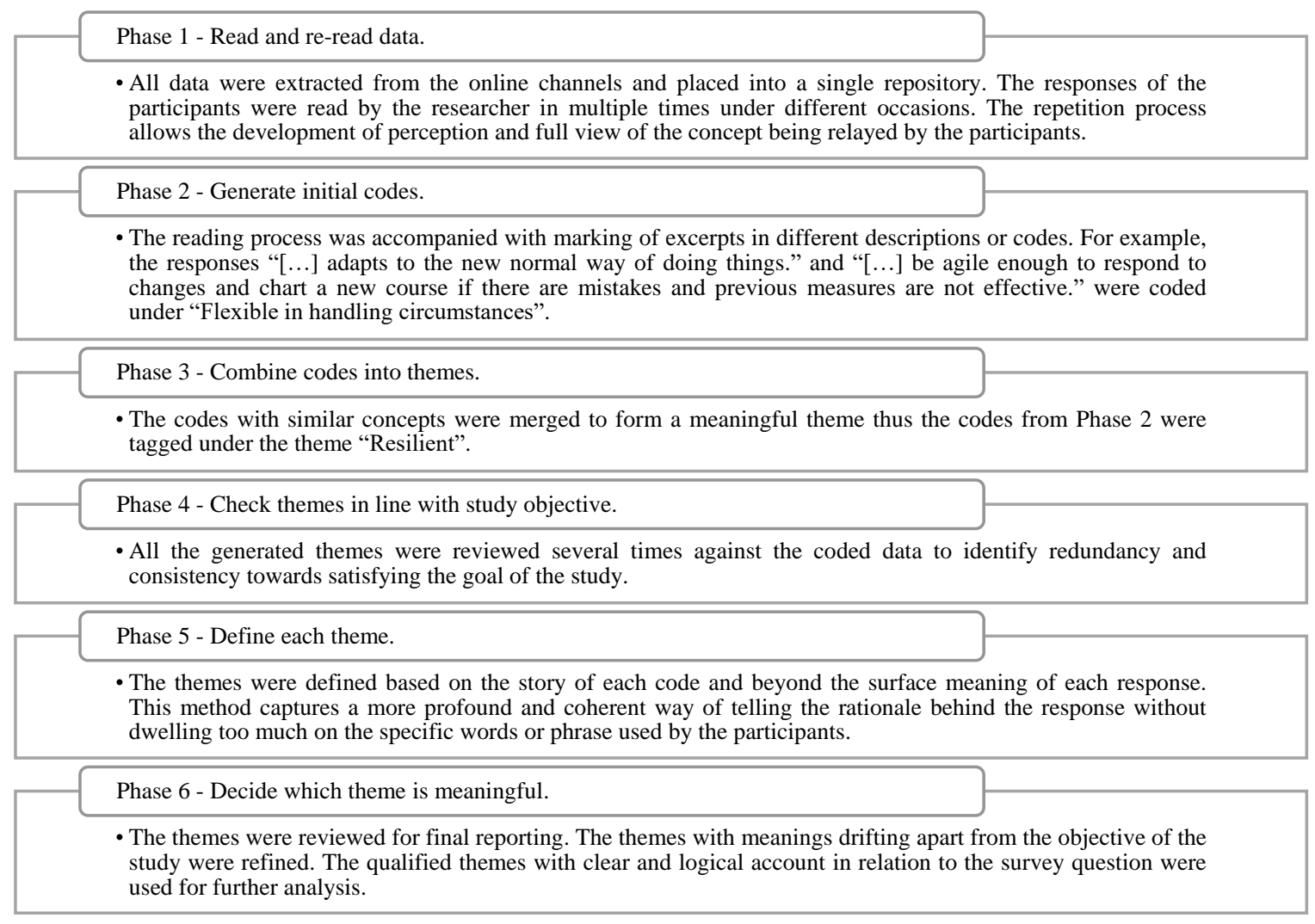

Figure 1. Thematic Analysis Procedures

\section{EMPIRICAL RESULTS}

\section{A. Descriptive Statistics}

The descriptive statistics of the study is presented in Table 1 . The majority of the participants were female with ages 25 to 30 years old and more than half of the total responses came from Davao City. All participants were working in the financial industry which included banks, insurance companies, and lending firms.

Table 1. Descriptive Statistics

\begin{tabular}{lccc}
\hline & Responses & Percentage \\
\hline Gender & Male & 14 & $31.8 \%$ \\
& Female & 44 & $68.2 \%$
\end{tabular}

This publication is licensed under Creative Commons Attribution CC BY.

http://dx.doi.org/10.29322/IJSRP.10.07.2020.p10307 
Age

$\begin{array}{ccc}25-30 & 22 & 37.9 \% \\ 31-35 & 19 & 32.7 \% \\ 36-40 & 17 & 29.4 \% \\ \text { Total } & 58 & 100.0 \%\end{array}$

Place of Work (City)

$\begin{array}{ccc}\text { Agusan } & 1 & 1.7 \% \\ \text { Bacolod } & 1 & 1.7 \% \\ \text { Cagayan de Oro } & 2 & 3.4 \% \\ \text { Cavite } & 1 & 1.7 \% \\ \text { Cebu } & 2 & 3.4 \% \\ \text { Davao } & 38 & 65.5 \% \\ \text { General Santos } & 2 & 3.4 \% \\ \text { Iligan } & 2 & 3.4 \% \\ \text { Lipa } & 1 & 1.7 \% \\ \text { Makati } & 1 & 1.7 \% \\ \text { Mandaue } & 1 & 1.7 \% \\ \text { Parañaque } & 2 & 3.4 \% \\ \text { Taguig } & 1 & 1.7 \% \\ \text { Tagum } & 1 & 1.7 \% \\ \text { Tandag } & 1 & 1.7 \% \\ \text { Tuguegarao } & 1 & 1.7 \% \\ \text { Total } & 58 & 100.0 \%\end{array}$

\section{B. Thematic Analysis}

The thematic analysis of leaders being resilient is presented in Table 2 with a total of 10 responses. During the time of difficulties, leaders are expected to be flexible and reliable in handling situations, patient in dealing with drastic changes, and determined to keep things moving forward.

Table 2. Thematic Analysis - Resilient

\begin{tabular}{|c|c|c|c|}
\hline Response & Excerpt & Code & Theme \\
\hline R1 & $\begin{array}{l}\text { "[...] keep things moving forward and adapts to the new } \\
\text { normal way of doing things." }\end{array}$ & $\begin{array}{l}\text { Flexible in handling } \\
\text { circumstances }\end{array}$ & \\
\hline R7 & $\begin{array}{l}\text { "[...] being ready in times like this pandemic we are going } \\
\text { through." }\end{array}$ & $\begin{array}{l}\text { Reliable in managing } \\
\text { situations }\end{array}$ & \\
\hline R17 & $\begin{array}{l}\text { "While driving people towards a common goal, he/she will be } \\
\text { needing patience as stress and tension is high and people are } \\
\text { coping with the pandemic differently." }\end{array}$ & Patient and determined & \\
\hline $\mathrm{R} 12$ & "Lenient. Compassionate. Quick decision maker." & Act prudently & \\
\hline R14 & $\begin{array}{l}\text { "One should have initiative without anyone asking them to do } \\
\text { things. Should act first and be a good example for the team." }\end{array}$ & Show initiative & Resilient \\
\hline R34 & $\begin{array}{l}\text { "[...] also be agile enough to respond to changes and chart a } \\
\text { new course if there are mistakes and previous measures are } \\
\text { not effective." }\end{array}$ & Sensibly resourceful & \\
\hline $\mathrm{R} 24$ & $\begin{array}{l}\text { "[...] leader should be adaptive to changes specially in this } \\
\text { time of Covid- } 19 \text { pandemic." }\end{array}$ & Adaptive to changes & \\
\hline R26 & "Resilient to face a crisis." & Able to handle challenges & \\
\hline R37 & $\begin{array}{l}\text { "Critical thinker, flexible or adaptive to a drastic change but } \\
\text { with compassionate heart" }\end{array}$ & Flexible to drastic change & \\
\hline
\end{tabular}


R50 "Positive outlook despite these challenging times." Optimistic

The thematic analysis of leaders being supportive is exhibited in Table 3 with a total of 6 responses. As organizations shift from in-office to work-from-home setup, leaders are assumed to show trust and confidence to their team members in executing assigned tasks and appreciate the team's effort through online collaboration and recognition.

Table 3. Thematic Analysis - Supportive

\begin{tabular}{|c|c|c|c|}
\hline Response & Excerpt & Code & Theme \\
\hline $\mathrm{R} 2$ & $\begin{array}{l}\text { "[...] he/she doesn't have to remind his/her team their tasks } \\
\text { frequently because his/her teammates already know their } \\
\text { tasks by heart }[\ldots] "\end{array}$ & Trust his/her team members & \\
\hline $\mathrm{R} 8$ & $\begin{array}{l}\text { "Trust is also very important. Show your team that you trust } \\
\text { them that they know how to handle their own areas. }[\ldots] "\end{array}$ & Show trust to his people & \\
\hline R11 & $\begin{array}{l}\text { "Have a Leader you can look up to who knows how to } \\
\text { motivate his people to do more than what is required. He } \\
\text { should know how to trust that his colleagues are working } \\
\text { more even from work-from-home." }\end{array}$ & $\begin{array}{l}\text { Express confidence to his } \\
\text { team members }\end{array}$ & Supportive \\
\hline R43 & $\begin{array}{l}\text { "The leader must build consensus among the various } \\
\text { stakeholders to ensure people have buy-in and are able to } \\
\text { work together smoothly." }\end{array}$ & Work with collaboration & \\
\hline $\mathrm{R} 22$ & $\begin{array}{l}\text { "A little recognition and appreciation of each and everyone's } \\
\text { hard work and sacrifice for the benefit of the } \\
\text { company/organization goes a really long way." }\end{array}$ & Appreciate the team's effort & \\
\hline R38 & "Also listens to co-employees concerns and opinions." & Open-minded & \\
\hline
\end{tabular}

The thematic analysis of leaders being supportive is described in Table 4 with a total of 18 responses. As the country's health care system struggles to combat the pandemic and organizations across industries tackle business survival, employees rethink their leaders as being sincere to know their health and safety, and considerate to extend emotional and financial support.

Table 4. Thematic Analysis - Empathetic

\begin{tabular}{|c|c|}
\hline Response & Excerpt \\
\hline R3 & $\begin{array}{l}\text { "[...] they make sure we have food to eat and some money to } \\
\text { spend during this pandemic. Since we need to go out to the } \\
\text { branch and serve the needs of our clients, they provide us } \\
\text { allowance in addition to our salary." }\end{array}$ \\
\hline R5 & $\begin{array}{l}\text { "Must be able to understand each team member's situation } \\
\text { and always be sincere with showing care and thoughtfulness } \\
\text { to the members }[\ldots] \text { " }\end{array}$ \\
\hline $\mathrm{R} 4$ & $\begin{array}{l}\text { "Aside from leading by example, taking into consideration } \\
\text { not only the loss of income but also the health of the } \\
\text { employees during this pandemic }[\ldots] \text { " }\end{array}$ \\
\hline R6 & $\begin{array}{l}\text { "Taking care of employees in the midst of pandemic. Making } \\
\text { them feel special and supported }[\ldots] "\end{array}$ \\
\hline R51 & $\begin{array}{l}\text { "[...] letting us know that they understand what we are going } \\
\text { through has a big impact to each one of us." }\end{array}$ \\
\hline $\mathrm{R} 45$ & $\begin{array}{l}\text { "[...] a little bit of 'Kumusta Ka?' would definitely brighten } \\
\text { up someone's rough day." }\end{array}$ \\
\hline $\mathrm{R} 13$ & $\begin{array}{l}\text { "At this time of pandemic, it is important that leaders in } \\
\text { organizations must have a compassion for their employees } \\
{[\ldots] \text { " }}\end{array}$ \\
\hline R18 & "In this trying time, employees need a leader who knows how \\
\hline
\end{tabular}
This publication is licensed under Creative Commons Attribution CC BY. http://dx.doi.org/10.29322/IJSRP.10.07.2020.p10307

Sincere in showing care

Consider health and safety of team members

Make sure their employees are okay

Understand the current difficulties

Kind and considerate

Care for others

Know how to empathize 
R21 "[...] it is important for the team to know that their leaders know and understand what they are going though. It is important for them to feel valued and heard."

R23 "A leader should put the welfare of his constituents first and make sure their safety, security, and basic needs are met before they make them do their jobs."

R28 "Understanding and listening to the team concerns and needs especially in terms of safety and wellbeing of the members put as top priority."

R31 "More than ever, employees need their companies to support them financially and emotionally. Because I believe that people is the bread and butter of any organization."

R32 "I think that a leader in an organization should be people oriented in this time of pandemic."

R39 "He must prioritize the welfare of his employees. To protect the company, he must protect the employees that made the company running."

R41 "Leaders should be patient in times troubles. Since we all know that this pandemic affects not only the profits of our business but leaders should take notice of the workforce (humans)."

R46 "[...] ensure that the employees' mental health is stable since the situation triggers anxiety and other negative thoughts."

R48 "Empathy over capitalism."

R52 "[...] the leader should understand the situation of their employees instead of terrorizing them."
Understand difficulties of the situation

Prioritize welfare of members

Listen to the team's concerns

Show genuine support

Attend to member's need

Prioritize employees

Considerate

Ensure sound working environment

Promote common good

Kind and compassionate

Considerate
Ensure sound working
environment
Promote common good
Kind and compassionate

Empathetic

The thematic analysis of leaders being transparent is shown in Table 5 with a total of nine responses. Communication plays a crucial part in the survival of any organization, thus effective leaders are considered as honest, objective and confident in communicating significant issues across various levels of the organization.

Table 5. Thematic Analysis - Transparent

\begin{tabular}{|c|c|}
\hline Response & Excerpt \\
\hline R9 & $\begin{array}{l}\text { "[...] communicate the facts to us and at the same time, let us } \\
\text { know the steps they are taking in this time of crisis. We will } \\
\text { feel that we have our boss and the company that we can rely } \\
\text { into }[\ldots] \text { ". }\end{array}$ \\
\hline $\mathrm{R} 10$ & $\begin{array}{l}\text { "A good leader during a pandemic is someone who is honest } \\
\& \text { has integrity, good decision maker, and confident." } \\
\text { "[...] as a leader, you have to communicate your intent every }\end{array}$ \\
\hline $\mathrm{R} 15$ & chance you get." \\
\hline R53 & $\begin{array}{l}\text { "The leader also must be firm and just, to apply decisions } \\
\text { with fairness and resolve [...]" }\end{array}$ \\
\hline $\mathrm{R} 35$ & $\begin{array}{l}\text { "In the midst of the COVID- } 19 \text { pandemic, a leader must keep } \\
\text { her/his people updated with the recent condition of the country } \\
\text { and of the company as a whole." }\end{array}$ \\
\hline R54 & $\begin{array}{l}\text { "Clear goal on vision and mission, good example, clear } \\
\text { communication, high integrity, good recognition." }\end{array}$ \\
\hline $\mathrm{R} 42$ & $\begin{array}{l}\text { "[...] communicating \& listening effectively are few of the } \\
\text { many attributes of being a leader that must put into action } \\
{[\ldots] \text { " }}\end{array}$ \\
\hline $\mathrm{R} 44$ & $\begin{array}{l}\text { "A Good Communicator and transparent leader. Someone } \\
\text { who can clearly communicate the goal and strategies for the } \\
\text { team." }\end{array}$ \\
\hline $\mathrm{R} 49$ & $\begin{array}{l}\text { "[...] not adverse to suggestions and comments from } \\
\text { subordinates, takes the "big picture" into consideration, } \\
\text { weighs what is important for the business while keeping }\end{array}$ \\
\hline
\end{tabular}

This publication is licensed under Creative Commons Attribution CC BY.

http://dx.doi.org/10.29322/IJSRP.10.07.2020.p10307

Truthful and confident

Good communicator

Objective and strong-minded

Communicate truthfully

Transparent

Role model

Communicate effectively

Communicate directions

Keep an open communication 
The thematic analysis of leaders being responsible is indicated in Table 6 with a total of 15 responses. Amidst the health crisis, leaders are thought to overlook the situations, guide the team members, and see opportunities for responsible headship.

Table 6. Thematic Analysis - Responsible

\begin{tabular}{|c|c|c|c|}
\hline Response & Excerpt & Code & Theme \\
\hline R55 & $\begin{array}{l}\text { "[...] a leader you should be responsible for the company's } \\
\text { survival." }\end{array}$ & Take responsibility & \\
\hline R16 & He should be a good listener and well decided in everything. & Lead and decide & \\
\hline R56 & $\begin{array}{l}\text { There must be a sense of mission for the greater good. He/she } \\
\text { will be looking after welfare of the people }[\ldots] \text { " }\end{array}$ & Overlook situations & \\
\hline R19 & "Grit and commitment." & Dedicated to work & \\
\hline $\mathrm{R} 20$ & $\begin{array}{l}\text { "Someone who doesn't waste people's time by having a } \\
\text { concrete objective, plans solutions and implementation." }\end{array}$ & Sincerity to serve & \\
\hline $\mathrm{R} 25$ & $\begin{array}{l}\text { "In my opinion, leaders in our organization must be } \\
\text { accountable, possess positive attitude and committed in this } \\
\text { time of pandemic." }\end{array}$ & Committed & \\
\hline $\mathrm{R} 27$ & $\begin{array}{l}\text { "A leader should still have the mindset of being goal oriented } \\
\text { without thinking of the impossible - the challenges in } \\
\text { attaining positive results for the company despite the } \\
\text { pandemic situation." }\end{array}$ & Guide the team & Responsible \\
\hline $\mathrm{R} 29$ & $\begin{array}{l}\text { "I think a good leader during this pandemic is someone who is } \\
\text { organize, someone who is calm. A clear mind is the best asset in } \\
\text { solving problems." }\end{array}$ & $\begin{array}{l}\text { Composed in dealing } \\
\text { challenges }\end{array}$ & \\
\hline R30 & $\begin{array}{l}\text { "At this time, a good leader should be decisive, giving clear and } \\
\text { solid directions in the midst of great uncertainty." }\end{array}$ & Focused to manage & \\
\hline R33 & $\begin{array}{l}\text { "A Leader with Concrete Plan. A Leader with Effective } \\
\text { Actions." }\end{array}$ & Visionary & \\
\hline R36 & $\begin{array}{l}\text { "He/she must create a positive attitude in implementing the new } \\
\text { norm in the branch and supports employer's new policies." }\end{array}$ & Positive thinker & \\
\hline
\end{tabular}


Table 6. Thematic Analysis - Responsible (continuation)

\begin{tabular}{clc}
\hline Response & \multicolumn{1}{c}{ Excerpt } & Code \\
\hline R40 & $\begin{array}{l}\text { "At times like this you need to think of solutions / opportunities } \\
\text { and always to have positive outlook." }\end{array}$ & Able to see opportunities \\
R47 & $\begin{array}{l}\text { "Goal driven, rational thinker [...]" } \\
\text { "Has the power to unite his/her team with same goal / objective; } \\
\text { h57 strong decision-making attitude [...]" }\end{array}$ & $\begin{array}{l}\text { Wise decision maker } \\
\text { Lead decision maker }\end{array}$ \\
R58 & $\begin{array}{l}\text { "In this chaotic and unprecedented situation, having a leader that } \\
\text { is quick to decide and act on the matters is very essential like in } \\
\text { our type of work as loan account officers." }\end{array}$ & Act responsibly \\
\end{tabular}

\section{Prevailing Traits}

The generated themes were ranked based on the weight distribution of responses to determine the most prevailing traits of leaders. The result in Figure 2 revealed that most employees highly perceived that their leaders, above all, should be empathetic, responsible and resilient.

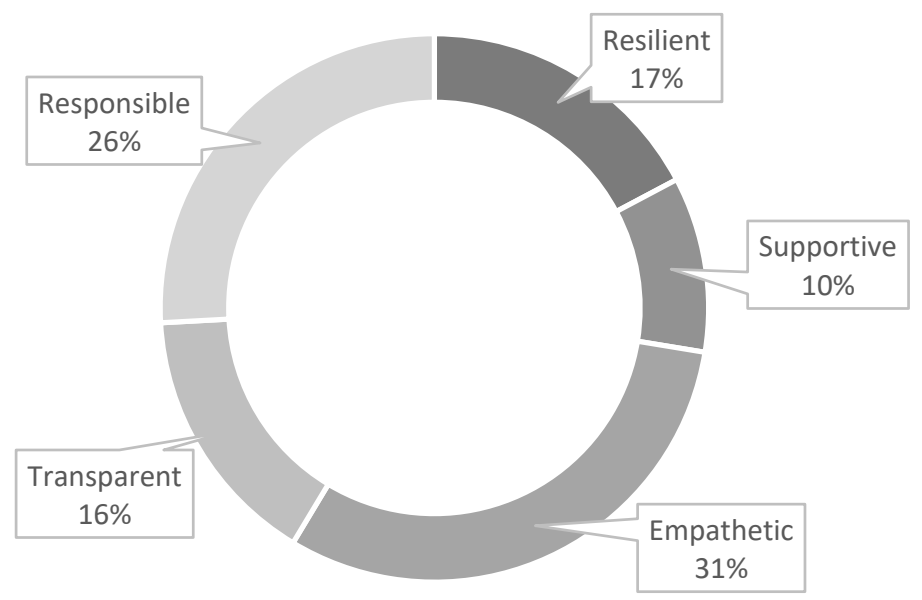

Figure 2. Leader's Prevailing Traits

\section{CONCLUSION AND RECOMMENDATION}

The study revealed that leaders become even more effective principals of organizations during the heath crisis if they are empathetic, responsible, resilient, transparent and supportive to their employees.

Empathetic leaders understand the concerns of their people, recognize their needs and sincere in showing care. They prioritize the welfare of their employees and create a sound working environment. They are more likely to become responsible leaders as well. Responsible leaders take the lead, overlook situations and discover opportunities. They build relationships that improve job satisfaction and promote organizational commitment. Resilient leaders can adapt to work pressures and process these to become prospects for growth. They are reliable, 
patient and determined to see light at the end of the tunnel. Transparent leaders are good listeners and better communicators. They are truthful, strong-minded, objective and confident in conversing clear directions for effective organizations. Lastly, supportive leaders are motivators who acknowledge the contribution of each member. They show trust and confidence in the works and decisions of their people. They collaborate to encourage creativity, train to develop expertise, and they reward performers for motivation.

Moreover, the study is recommended to all organization leaders across industries. With the results, leaders may proactively improve their strategies in dealing with financial, emotional and social implications caused by the COVID-19 pandemic. The identified prevailing traits are necessary for leaders to possess so that employees may see confidence, hope and relief. Nonetheless, the study is endorsed to the community of scholars for further review and exploration of the subject using various scientific approaches.

\section{REFERENCES}

Atwater, L.E., \& Waldman, D.A. (2008). Leadership, feedback and the open communication gap. (1st ed.). New York: Taylor \& Francis Group, LLC.

Bar-On, R., \& Parker, J.D.A. (2000). The handbook of emotional intelligence. San Francisco, CA: Jossey-Bass Inc.

Bass, B.M. (1985). Leadership and performance beyond expectations. New York: Free Press.

Brearley, B. (2020). Supportive leadership behaviours that will see your team thrive. Thoughtful Leader. Retrieved from https://www.thoughtfulleader.com/supportive-leadership-behaviours/

Burney, S.M.A., Saleem, H. (2008). Inductive \& deductive Research approach. Lecture delivered on 06-03-2008 at Auditorium of Faculty of Arts and Science, University of Karachi, Karachi, Pakistan.

Conger, J.A., \& Kanungo, R.N. (1998). Charismatic leadership in organizations. Thousand Oaks, CA, US: Sage Publications, Inc.

Corbin, J., \& Strauss, A. (2008). Basics of qualitative research: Techniques and procedures for developing grounded theory (3rd ed.). Thousand Oaks, CA: Sage.

Corporate Finance Institute. (2020). Supportive leadership. A leadership style that supports an employee until a task's completion. Retrieved from https://corporatefinanceinstitute.com/resources/careers/soft-skills/supportive-leadership/

Crant, J.M., \& Bateman, T.S. (2000). Charismatic leadership viewed from above: the impact of proactive personality. Journal of Organizational Behavior, Volume 21, Issue 1. Wiley Onlie Library. https://doi.org/10.1002/(SICI)1099-1379(200002)21:1<63::AID-JOB8>3.0.CO;2-J

Decety, J., Philip, L., \& Jackson, P.L. (2006) A social-neuroscience perspective on empathy. Current Directions in Psychological Science, 15, 54-58. http://dx.doi.org/10.1111/j.0963-7214.2006.00406.x

Derue, D.S., Nahrgang, J.D., Wellman, N., \& Humphrey, S.E. (2011). Trait and behavioral theories - of leadership: An integration and metaanalytic test of their relative validity. Personnel Psychology, 4(1), 7-52.

Dietz, J., \& Kleinlogel, E.P. (2014). Wage cuts and managers' empathy: How a positive emotion can contribute to positive organizational ethics in difficult times. Journal of Business Ethics, 119, 461-472. http://dx.doi.org/10.1007/s10551-013-1836-6

Digman, J.M. (1990). Personality structure: Emergence of the five-factor model. Annual Review of Psychology, 41, 417-440.

Doh, J.P., \& Quigley, N.R. (2014) Responsible leadership and stakeholder management: Influence pathways and organizational outcomes. The This publication is licensed under Creative Commons Attribution CC BY.

http://dx.doi.org/10.29322/IJSRP.10.07.2020.p10307 www.ijsrp.org 
International Journal of Scientific and Research Publications, Volume 10, Issue 7, July 2020

ISSN 2250-3153

Academy of Management Perspectives, 28, 255-274. http://dx.doi.org/10.5465/amp.2014.0013

Doh, J.P., Stumpf, S.A., \& Tymon Jr., W.G. (2011) Responsible leadership helps retain talent in India. Journal of Business Ethics, 98, 85-100. http://dx.doi.org/10.1007/s10551-011-1018-3

Gardner, L., \& Stough, C. (2002). Examining the relationship between leadership and emotional intelligence in senior level managers. Leadership \& Organizational Development Journal, 23(2), 68-78.

Gardner, W.L., Avolio, B.J., Luthans, F., May, D. R., \& Walumbwa, F.O. (2005). Can you see the real me? A self-based model of authentic leader and follower development. The Leadership Quarterly, 16(3), 343-372.

Gentry, W.A., Weber, T.J., \& Sadri, G. (2016). Empathy in the workplace. A tool for effective leadership. White Paper, Center for Creative Leadership.

George, J.M. (2000). Emotions and leadership: The role of emotional intelligence. Human Relations, 53, 1027-1055.

Goldberg, L.R. (1993). The structure of phenotypic personality traits. The American Psychologist. 48(1): 26-34. doi:10.1037/0003066X.48.1.26. PMID 8427480.

Goleman, D. (2000). Leadership that gets results. Harvard Business Review, 78(2), 78-90

Gross, C.U. (2002). Managing communication within virtual intercultural teams. Business Communication Quarterly, 65(4), 22-38

Han, Yi. (2017). How leaders' transparent behavior influences employee creativity. Retrieved from https://www.researchgate.net/publication/319301490

Hersey, P., \& Blanchard, K.H. (1969). Management of organizational behavior - Utilizing human resources. New Jersey/Prentice Hall.

Hill, C.E., Thompson, B.J., \& Williams, E.N. (1997). A guide to conducting consensual qualitative research. The Counselling Psychologist, 25, $517-572$.

Hough, L.M. (1992). The "Big Five" personality variables - Construct confusion: Description versus prediction. Human Performance, 5, 139155.

Hughes, L.W. (2005). The spirit of GIVE: Relational transparency and humor in authentic leader-follower relationships. In W.L. Gardner \& B.J. Avolio (Eds.), Authentic leadership development: Monographs in leadership and management series (vol. 3), Boston, MA: Elsevier, JAI Press.

Joy, Manu. (2017). Resilient Leadership. Pallikkutam.

Judge, T.A., Bono, J.E., Ilies, R., \& Gerhardt, M.W. (2002). Personality and leadership: A qualitative and quantitative review. Journal of Applied Psychology, 87, 765-780.

Kay, B., \& Christophel, D.M. (1995). The relationships among manager communication openness, nonverbal immediacy, and subordinate motivation. Communication Research Reports, 12, 200-205.

Klauss, R., \& Bass, B.M. (1982). Interpersonal communication in organizations. New York, NY: Academic Press.

Kouzes, J., \& Posner, B. (2019). The authors of the leadership challenge. The Leadership Challenge.

Krystal, J.H. (2008). Resilience: Accommodation and recovery. In J. Parens, H. Blum, \& S. Akhtar (Eds.), The unbroken soul: Tragedy, trauma and resilience. Lanham, MD: Jason Aronson.

Kruger, J., \& Dunning, D. (1999). Unskilled and unaware of it: How difficulties in recognizing one's own incompetence lead to inflated selfassessments. Journal of Personality and Social Psychology, 77, 1121-1134.

Kumar, S., Adhish, V.S., \& Deoki, N. (2014). Making sense of theories of leadership for capacity building. Indian J Community Med. doi:10.4103/0970-0218.132721

Lane, Andrea (2019). 11 ways highly successful leaders support their team. Redbooth. Retrieved from https://redbooth.com/hub/successfulleaders-support-their-team/

This publication is licensed under Creative Commons Attribution CC BY.

http://dx.doi.org/10.29322/IJSRP.10.07.2020.p10307

www.ijsrp.org 
International Journal of Scientific and Research Publications, Volume 10, Issue 7, July 2020

ISSN 2250-3153

Leonard, D. (1999). Creative abrasion. In D. Leonard (Ed.), When sparks fly: Igniting creativity in groups. Boston, MA: Harvard Business School.

Llopis, G. (2012). 5 Powerful things happen when a leader is transparent. Forbes. Retrieved from https://www.forbes.com/sites/glennllopis/2012/09/10/5-powerful-things-happen-when-a-leader-is-transparent/\#2d28a6c64a3a

Lord, R.G., De Vader, C.L., \& Alliger, G.M. (1986). A meta-analysis of the relation between personality traits and leadership perceptions: An application of validity generalization procedures. Journal of Applied Psychology, 71, 402-410.

Maak, T., \& Pless, N.M. (2006) Responsible leadership in a Stakeholder society-A relational perspective. Journal of Business Ethics, 66, 99115. http://dx.doi.org/10.1007/s10551-006-9047-z

Marques, J. (2010). Spirituality, meaning, interbeing, leadership, and empathy: Smile. Interbeing, 4(2), 7- 17.

Martinovski, B., Traum, D., \& Marsella, S. (2007). Rejection of empathy in negotiation. Group Decision \& Negotiation, 16(1), 61-76.

Mencl, J., \& May, D. (2009). The effects of proximity and empathy on ethical decision-making: An exploratory investigation. Journal of Business Ethics, 85(2), 201-226.

Muller, A.R., Pfarrer, M.D., \& Little, L.M. (2014). A theory of collective empathy in corporate philanthropy decisions. Academy of Management Review, 39, 1-21. http://dx.doi.org/10.5465/amr.2012.0031

Myers, S.A., Knox, R.L., Pawlowski, D.R., \& Ropog, B.L. (1999). Perceived communication openness and functional communication skills among organizational peers. Communication Reports, 12(2), 71-83.

Oakleaf, L. (2016). Trait theory of leadership. Organization and Administration in Recreation, Sport and Leisure Management. Missouri Western.

Reich, J.W., Zautra, A.J., \& Hall, J.S. (2010). In J. W. Reich, A.J. Zautra, \& J.S. Hall (Eds.), Handbook of Adult Resilience. New York, NY: Guilford Press.

Reivich, K., \& Shatte, A. (2003). The resilience factor: Seven keys to finding your inner strength and overcoming life's hurdles. New York, NY: Broadway Books.

Robbins, S.P. (2003). Organization Behavior. $10^{\text {th }}$ ed. New Jersey: Prentice Hall.

Salgado, J.F. (1997). The five-factor model of personality and job performance in the European Community. Journal of Applied Psychology, 82(1), 30-43. https://doi.org/10.1037/0021-9010.82.1.30

Salovey, P., \& Mayer, J.D. (1990). Emotional intelligence. Imagination, Cognition and Personality, 9, 185-211.

Stahl, G.K., \& de Luque, M.S. (2014) Antecedents of responsible leader behavior: A research synthesis, conceptual framework, and agenda for future research. The Academy of Management Perspectives, 28, 235-254. http://dx.doi.org/10.5465/amp.2013.0126

Simmons, B.L. (2010). Nine supportive leadership behaviours. Retrieved from http://www.bretlsimmons.com/2010-09/nine-supportiveleadership-behaviors/

South China Morning Post. (2020). Coronavirus: China's first confirmed Covid-19 case traced back to November 17. Retrieved from https://www.scmp.com/news/china/society/article/3074991/coronavirus-chinas-first-confirmed-covid-19-case-traced-back.

Southwick, S.M., Litz, B.T., Charney, D., \& Friedman, M.J. (Eds.). (2011). Resilience and mental health: Challenges across the lifespan. Cambridge, England: Cambridge Press.

Southwick, F., Martini, B., Charney, D., \& Southwick, S. (2017). Leadership and resilience. 10.1007/978-3-319-31036-7_18.

Spector, B. (2016). Carlyle, Freud and the great man theory more fully considered. Leadership. doi: 10.1177/1742715015571392.

Stevens, C.D., \& Ash, R.A. (2001). Selecting employees for fit: Personality and preferred managerial style. Journal of Managerial Issues.

Tager, M. (2004). What people really need from a change leader. Leader to Leader, 31, 6-9

This publication is licensed under Creative Commons Attribution CC BY.

http://dx.doi.org/10.29322/IJSRP.10.07.2020.p10307

www.ijsrp.org 
Time. (2020). World Health Organization declares COVID-19 a 'pandemic. Here's what that means. Retrieved from https://time.com/5791661/who-coronavirus-pandemic-declaration/.

Tupes E.C., \& Raymond, E.C. (1961). Recurrent personality factors based on trait ratings. USAF ASD Tech. Rep. 60 (61-97): 22551. doi:10.1111/j.1467-6494.1992.tb00973.x. PMID 1635043.

Voegtlin, C. (2011) Development of a Scale Measuring Discursive Responsible Leadership. Journal of Business Ethics, 98, 57-73. http://dx.doi.org/10.1007/s10551-011-1020-9

Voss, R., Gruber, T., \& Reppel, A. (2010). Which classroom service encounters make students happy or unhappy? International Journal of Educational, 24(7), 615-636.

Walumbwa, F.O., Avolio, B.J., Gardner, W.L., Wernsing, T.S., \& Peterson, S.J. (2008). Authentic leadership: Development and validation of a theory-based measure. Journal of Management, 34, 89-126.

Weiss, W.H. (2002). Organizing for quality, productivity, and job satisfaction. Supervision, 63(2), 13-15

World Health Organization. (2020). WHO timeline - COVID - 19. Retrieved from https://www.who.int/news-room/detail/27-04-2020-whotimeline---covid-19.

Yehuda, R., Flory, J.D., Southwick, S., \& Charney, D.S. (2006). Developing an agenda for translational studies of resilience and vulnerability following trauma exposure. Annals of the New York Academy of Sciences, 1017, 379-396.

Yukl, G. (2006). Leadership in Organisations (6th ed.). Upper Saddle River, New Jersey: Pearson Prentice Hall.

Yukl, G. (2010). Leadership in Organizations. Upper Saddle River, NJ: Pearson.

Zaccaro, S.J., Kemp, C., \& Bader, P. (2004). Leader traits and attributes. The nature of leadership. (pp. 101-124). Thousand Oaks, CA, US: Sage Publications, Inc.

\section{AUTHOR}

Dr. Erick John E. Endres, Finance Professor, School of Business and Governance, Ateneo de Davao University, Davao City, Philippines, Email: ejeendres@addu.edu.ph / erickjohn.endres@gmail.com 